\title{
Ropivacaine plus lidocaine versus Bupivacaine plus lidocaine for peribulbar double injection regional anesthesia
}

\author{
Omar Elsafty MD, Ahmed M.S. Hamed MD, Sherif Wadie MD \& \\ *Ahmed Shoeir MD
}

\author{
Departement of anesthesia Ain shams university \\ * Research institute of ophthalmology
}

\begin{abstract}
:
Our study was designed to evaluate the efficacy of Ropivacaine $0.75 \%$ plus Lidocaine $2 \%$ versus Bupivacaine $0.5 \%$ plus lidocaine $2 \%$ to provide peribulbar anaesthesia for cataract surgery .Time to adequate block for surgery, ocular eyelid movement scores at 8 min after block and quality for postoperative analgesia were recorded. Sixty patients are randomly divided into two groups of 30 , to receive a peribulbar block with $8-10 \mathrm{ml}$ of either Ropivacaine - Lidocaine or Bupivacaine - lidocaine, and 15U Hyaluridase per ml with each combination .

There was no difference between the two groups in clinical endpoint, Median time at which the block was adequate to start surgery was $8 \mathrm{~min}$. (4-10 min ) in each group . Median eyelid movement scores were similar in both groups, yet the lower potential for systemic toxicity of ropivacaine compared with bupivacaine enables it to be used for surgical anesthesia in higher concentration which may facilitate diffusion of local anesthetic molecules into peripheral nervous tissue, improving the onset of nerve blockade.
\end{abstract}

\section{Introduction:}

Regional anesthesia with peribulbar block is the technique of choice for most patients undergoing cataract surgery (1). A mixture of bupivacaine and lidocaine is the most frequently used local anesthetic, lidocaine providing a rapid onset and bupivacaine a long duration of action . (2)Ropivacaine has the potential advantage of reduced cardiovascular and neurological toxicity compared with other local anesthetics that are commonly used for peribulbar anesthesia. However, the motor sparing attributed to ropivacaine is a potential disadvantage that might reduce the onset of motor block required for ophthalmic surgery(3).Hyaluronidase hydrolyses the $\mathrm{C} 1-\mathrm{C} 4$ bonds between glucosamine and glucuronic acid in ground substance ,thus promoting spread of anaesthetic through the tissue .The proposed advantages of using hyaluronidase include enhanced speed of onset and improved operating condition (4).

\section{Patients \& method:}

After having approved written consent from each patient, sixty ASA physical status I ,II,OR III patients scheduled for cataract surgery with expected duration of < 90 min were included .Patients allergic to local anesthetic solutions, with local sepsis , serious impairment of coagulation, and orbital abnormalities, or who were unable to cooperate in maintaining a relatively motionless supine position or who refuse the anesthetic technique were not included. All patients underwent topical anesthesia of the conjunctiva using 2-3 drops of $0.4 \%$ oxybuprocaine and premedicated with 0.03 $-0.05 \mathrm{mg} / \mathrm{kg}$ medazolam together with $0.2-0.4 \mathrm{Ug} / \mathrm{kg}$ fentanyl I.V.

Patients were randomly divided into two equal groups each of 30 patients, Group $\mathrm{R}$ who received preibulbar block with $8-10 \mathrm{ml}$ of mixture of ropivacaine $0.75 \%$ \& lidocaine $2 \% \quad 1: 1$, and group B who received the same volume of local anesthetic with a mixture of bupivacaine $0.5 \%$ \& lidocaine $2 \% 1: 1$. The amount of anesthetic mixture injected was determined by the degree of lid fullness and the intraorbital pressure assessed. 


\section{Omar Elsafty MD et al}

Standard monitoring, including noninvasive arterial blood pressure, electrocardiogram, heart rate, and peripheral Sao2 was used. All these data are recorded every $5 \mathrm{~min}$ until completion of surgery.

Local anesthetic solution $0.5-1 \mathrm{ml}$ was injected into the orbicularis muscle and in the subcutaneous area using short insulin needle at the level of inferior orbital rim and the superonasal quadrant .Aktinson needle (23-gauge ,3.1 cm in length) was inserted at the level of inferior orbital floor to a depth of approximately $2.5 \mathrm{~cm}$. Five $\mathrm{ml}$ of local anesthetic solution was injected. In the same way, $3 \mathrm{ml}$ was injected at the superonasal quadrant along the superior orbital roof . Different volumes of local anesthetic were used depending on the degree of filling of the orbit observed during injection and the rate of onset of ptosis. Manual compression and gentle massage of the eyeball were performed after which a visitec intraocular pressure reducer inflated to $40 \mathrm{~mm} \mathrm{Hg}$ was applied between scoring to facilitate spread of the local anesthetic solution and to lower the intraocular pressure .Patients are assessed for eyelid and ocular movements at $2 \mathrm{~min}$ intervals using the scoring system of Brahama and colleagues.

Ocular movements were scored for each direction of gaze in the superior, inferior, median and lateral direction with a maximum score for each direction of three points and a possible total maximum score of 12 points. Ocular and eyelid movements were assessed at 2, 4, 6, 8 \& 10 min until the block was considered adequate for surgery (eyelid movement score $=0$ and ocular movement score $<2$ ).

\section{Results:}

The main outcome criteria were different in median ocular and eyelid movement scores at 8 minutes and time needed to obtain adequate block to start surgery. Differences between groups were analyzed using the Wilcoxon rank sum test. The number of patients who reached an ocular movement score of $\leq \mathbf{2}$, need for further injections and delay to the start of surgery were compared using the Fisher's exact test. Statistical analysis was carried out using SPSS for windows version 8.

There were 30 patients in each group and all patient data were included in the statistical analysis.

Median eyelid movement scores were not significantly different between groups at any time, but there was highly significant decrease in median eyelid movement scores in ropivacaine and bupivacaine groups from 2-4 minutes ( P: .003 \& P: .012) and from 4 - 6 minutes ( P: .005 \& P: .003) respectively, ( table 1).

Ocular movement scores were only significantly decreased in the bupivacaine group compared with the ropivacaine group at 2 minutes ( P: 0.013 ). And there was highly significant decrease in median ocular movement scores in ropivacaine group from 4- 6 minutes ( P: .001) and in bupivacaine group from $4-6$ minutes ( P: .002) and from 6-8 minutes ( P: .001) see table 1 .

Twenty seven patients in the ropivacaine group and 28 patients in the bupivacaine group had ocular movement scores of $\leq 2$ at 8 minutes.

None of the patients had failure of the block, nor needed supplementary dose in either of the groups.

Table 1 Median (interquartile range ) ocular and eyelid movement scores of the two groups. $* \mathrm{P}<0.05$ between groups and $\uparrow \mathrm{P} \leq 0.001$ between minutes in each group

\begin{tabular}{|lll|}
\hline & $\begin{array}{l}\text { Ropivacaine } \\
0.75 \% \text { and } \\
\text { lidocaine } \\
(\mathrm{n}=30)\end{array}$ & $\begin{array}{l}\text { Bupivacaine } \\
0.5 \% \text { and } 2 \% \\
\text { lidocaine } \\
(\mathrm{n}=30)\end{array}$ \\
\hline $\begin{array}{l}\text { Ocular } \\
\text { movement } \\
\text { scores }\end{array}$ & & \\
2 min & $5(2-9)$ & $4(2-7)^{*}$ \\
4 min & $4(1-8)$ & $3(2-6)$ \\
6 min & $3(1-5) \dagger$ & $2(1-5) \dagger$ \\
8 min & $2(1-5)$ & $2(0-3) \dagger$ \\
Eyelid & & \\
movement & & \\
scores & & $1(0-2)$ \\
2 min & $1(0-2)$ & $1(0-2) \dagger$ \\
4 min & $1(0-2) \dagger$ & $0(0-2) \dagger$ \\
6 min & $0(0-2) \dagger$ & $0(0-1)$ \\
8 min & $0(0-1)$ & \\
\hline
\end{tabular}




\section{Discussion :}

The goal of this study was to compare the effect of two local anesthetics, bupivacaine and ropivacaine ,each administered with lidocaine, on the quality of the block obtained after peribulbar anesthesia by supra and infra ocular injection.

From the previous results we noticed that with equal amount of local anesthetics and with the same dose and concentration , clinical studies proved that with respect to onset, duration, and extent of sensory block, ropivacaine is similar to bupivacaine .This was in concordance with Gillart and his colleagues (6), who got the same results ,yet they noticed that ropivacaine produced a less potent motor block at the same concentration but they preferred using ropivacaine for its greater margin of safety which means it can be used in high concentrations. It was found to be less toxic to the heart and central nervous system , and in healthy volunteers, it led only to mild symptoms of central nervous system toxicity at doses $25 \%$ higher than bupivacaine, while evidence of reduced cardiac conductivity and contractility appeared at doses 33\% larger, and at plasma concentration levels 38\% larger. For this reason ,ropivacaine may be a more appropriate anesthetic for peribulbar anesthesia than bupivacaine and the motor block being mainly achieved by adding lidocaine

Woodward and his colleagues (3), used ropivacaine as a sole anesthetic agent for peribulbar block, yet they had to add high concentrations of hyaluronidase (300 IU) to give onset and quality of peribulbar block equivalent to $0.5 \%$ bupivacaine with $2 \%$ lidocaine with 50 IU hyaluronidase .

Gioia and his colleagues (7), found that the lower potential for systemic toxicity of ropivacaine compared with bupivacaine enables it to be used for surgical anesthesia in concentrations up to 1 $\%$, this higher concentration may facilitate diffusion of local anesthetic molecules into peripheral nervous tissue, improving the onset of nerve blockade. In this study 60 patients were received peribulbar block with either ropivacaine plain or bupivacaine with lidocaine 1:1 mixture, time required for onset of surgical anesthesia were shorter in bupivacaine - lidocaine group $\left(8++_{-} 5\right.$ $\mathrm{min})$ than in ropivacaine $(10 \pm 5 \mathrm{~min})$ as a sole anesthetic agent, but $83 \%$ of the ropivacaine group did not require pain medication compared with bupivacaine lidocaine group $66 \%$. This was not surprising for them because patients in $\mathrm{R}$ group received 3 times as much ropivacaine compared with the amount of bupivacaine administered in the $\mathrm{B}$ group and this observation may have clinical relevance when deciding which better local anesthetic solution to be used.

\section{References:}

1. Nicholson G, Sutton B, Hall GM. Comparison of $1 \%$ ropivacaine with $0.75 \%$ bupivacaine and $2 \%$ lidocaine for peribulbar anaesthesia. Br J Anaesth 2000; $84: 89-91$.

2. Wong DHW. Regional anaesthesia for intraocular surgery. Can J Anaesth 1993; 40 : $635-57$.

3. Woodward DK, Leung ATS, Tse MWI, Law RWK, Lam DSC, Ngan Knee WD. Peribulbar anaesthesia with $1 \%$ ropivacaine and hyaluronidase $300 \mathrm{IU} \mathrm{ml}^{-1}$ : comparison with $0.5 \%$ bupivacaine $/ 2 \%$ lidocaine and hyaluronidase $50 \mathrm{IU} \mathrm{ml} \mathrm{m}^{-1}$. $\mathrm{Br} \mathrm{J}$ Anaesth 2000; $85: 618-620$.

4. Mantovani C, Bryant AE, Nicholson G. Efficacy of varying concentrations of hyaluronidase in peribulbar anaesthesia. $\mathrm{Br}$ J Anaesth 2001; $86: 876-878$.

5. Brahama AK, Pemberton CJ, Ayeko M, Morgan LH. Single medial injection peribulbar anaesthesia using prilocaine. Anaesthesia 1994; 49 : 1003 - 5.

6. Gillart T, Barrau P, Bazin JE, Roche G, Chiambaretta F, Schoeffler P. Lidocaine Plus Ropivacaine Versus Lidocaine Plus Bupivacaine for Peribulbar Anesthesia by Single Medial Injection. Anesthesia and Analgesia 1999; 89 : 1192 - 6 .

7. Gioia L, Prandi E, Codenotti M, Casati A, Fanelli G, Torri TM, Azzolini C, Torri G. Peribulbar Anesthesia with Either $0.75 \%$ Ropivacaine or a $2 \%$ Lidocaine and $0.5 \%$ Bupivacaine Mixture for Vitreoretinal Surgery: A Double-Blinded Study. Anesthesia and Analgesia 1999; 89 : 739 42. 


\section{دراسة مقارنة بين عقار البيوبيفاكين و عقار الروبيفاكين في التخدير حول مقلة العين}

$$
\begin{aligned}
& \text { *د.عمر الصفتى , *د.أحمد شفيق, *د.شريف وديع, **د.أحمد شعير }
\end{aligned}
$$

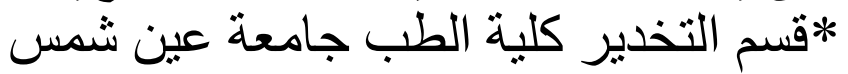

$$
\begin{aligned}
& \text { (معهد الرمد القومي جامعة كين }
\end{aligned}
$$

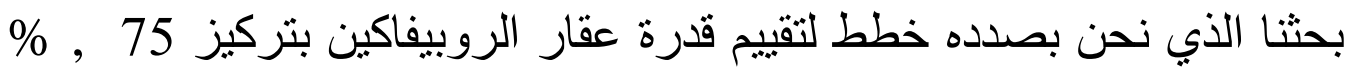

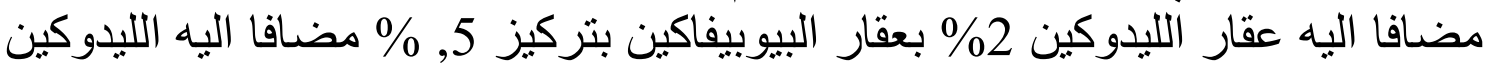
2\% و ذاللك في حالات التخدير حول مقلة العين في عمليات الئياه البيضاء. تم تسجيل الوقت الكافي لتخدير العين و حركة الجفون و درجة تخفيف الألم بعد اجر اء اءلياء

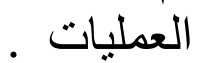

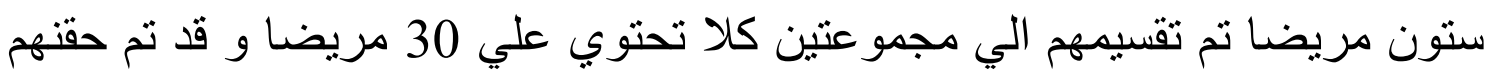

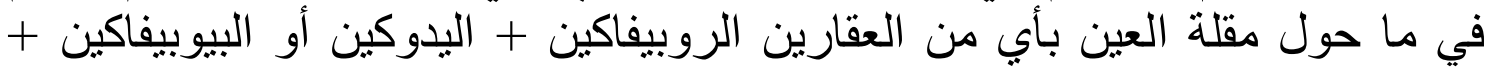

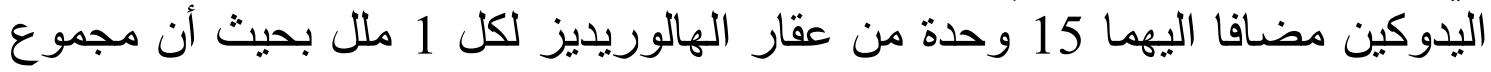

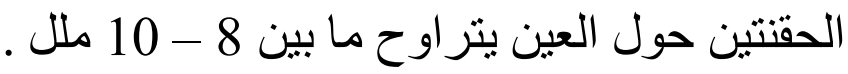

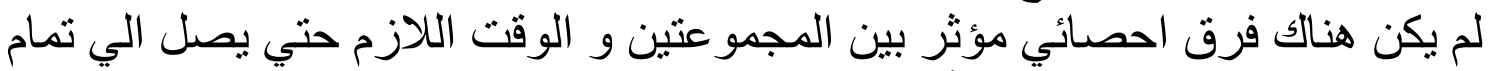

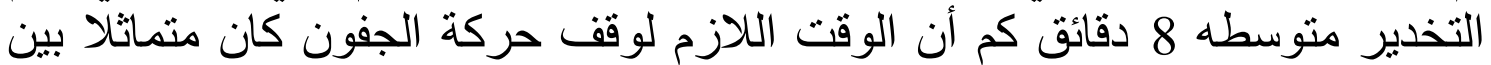

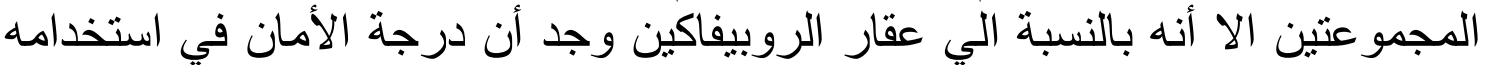

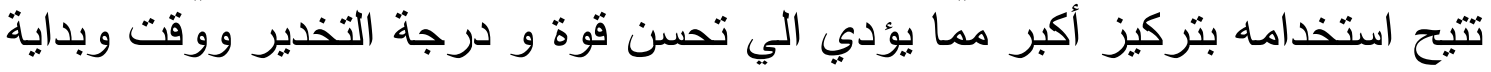

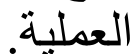

